\title{
POLITICOS:
}

Jurnal Politik dan Pemerintahan

https://www.ejournal.warmadewa.ac.id/index.php/politicos/index

\section{Peran Pemerintah Kota Denpasar Dalam Mengakomodasi Hak Penyandang Disabilitas Dalam Memperoleh Pekerjaan}

\author{
Komang Ema Marsitadewi ${ }^{1 *}$ dan Ida Ayu Putu Sri Widnyani² \\ ${ }^{1}$ Fakultas Ilmu Sosial dan Ilmu Politik, Universitas Warmadewa, Denpasar-Indonesia \\ ${ }^{2}$ Fakultas Ilmu Sosial dan Ilmu Politik, Universitas Ngurah Rai, Denpasar-Indonesia \\ Corespondence Email: *ema.marsitadewi@warmadewa.ac.id
}

How to Cite: Marsitadewi, K. E., \& Widnyani, I. A. P. S. (2021). Peran Pemerintah Kota Denpasar Dalam Mengakomodasi Hak Penyandang Disabilitas Dalam Memperoleh Pekerjaan. POLITICOS: Jurnal Politik dan Pemerintahan, 1 (2): 98-112. Doi: https://doi.org/10.22225/politicos.1.2.2021.98-112

\section{Abstract}

The existence of a disability label attached to a person with a disability makes it difficult for people with disabilities to find work. Whereas, in accordance with human rights, persons with disabilities should have the same rights as the general public in obtaining employment. Coupled with the existence of a legal umbrella in the protection and fulfillment of the rights of persons with disabilities in Bali, namely Regional Regulation No. 9 of 2015 concerning the Protection and Fulfillment of the Rights of Persons with Disabilities which can be the basis for fulfilling the rights of persons with disabilities in Bali. This includes the fulfillment of job rights for persons with disabilities. The method used is a qualitative method. Primary data were obtained by direct observation and field interviews with informants. While secondary data is obtained from reports related to persons with disabilities in accessing work. The results show that the government's role in the empowerment function is still weak. This can be seen from the training activities held by the Denpasar City Social Service and the Denpasar City Manpower Service. The training provided has varied, but due to budget constraints, it seems that the training provided is rare and underdeveloped for some people with disabilities. In addition, the lack of data collection causes the government to tend to invite only disability organizations. So that people with disabilities outside the organization are less aware of information related to the training provided by the government. This study recommends that the Denpasar City Social Service and Denpasar City Manpower Office improve socialization so that job providers will be more sensitive to the rights of persons with disabilities which should be the same as other communities in general.

Keywords: employment; government role; persons with disabilities.

\begin{abstract}
Abstrak
Adanya label disabilitas yang melekat pada penyandang disabilitas membuat penyandang disabilitas sulit mendapatkan pekerjaan. Padahal, sesuai dengan hak asasi manusia, penyandang disabilitas harus memiliki hak yang sama dengan masyarakat umum dalam memperoleh pekerjaan. Ditambah dengan adanya payung
\end{abstract}


hukum dalam perlindungan dan pemenuhan hak penyandang disabilitas di Bali yaitu Peraturan Daerah Nomor 9 Tahun 2015 tentang Perlindungan dan Pemenuhan Hak Penyandang Disabilitas yang dapat menjadi dasar pemenuhannya. hak-hak penyandang disabilitas di Bali. Termasuk di dalamnya pemenuhan hak kerja bagi penyandang disabilitas. Metode yang digunakan adalah metode kualitatif. Data primer diperoleh dengan observasi langsung dan wawancara lapangan dengan informan. Sedangkan data sekunder diperoleh dari laporan terkait penyandang disabilitas dalam mengakses pekerjaan. Hasil penelitian menunjukkan bahwa peran pemerintah dalam fungsi pemberdayaan masih lemah. Hal ini terlihat dari kegiatan pelatihan yang diadakan oleh Dinas Sosial Kota Denpasar dan Dinas Tenaga Kerja Kota Denpasar. Pelatihan yang diberikan bervariasi, namun karena keterbatasan anggaran, tampaknya pelatihan yang diberikan jarang dan kurang berkembang bagi sebagian penyandang disabilitas. Selain itu, minimnya pendataan menyebabkan pemerintah cenderung hanya mengundang organisasi disabilitas. Sehingga penyandang disabilitas di luar organisasi kurang mengetahui informasi terkait pelatihan yang diberikan oleh pemerintah. Penelitian ini merekomendasikan agar Dinas Sosial Kota Denpasar dan Disnaker Kota Denpasar meningkatkan sosialisasi agar pemberi kerja lebih peka terhadap hak-hak penyandang disabilitas yang seharusnya sama dengan masyarakat lain pada umumnya.

Kata Kunci: pekerjaan; peran pemerintah; penyandang disabilitas.

\section{PENDAHULUAN}

Penyandang disabilitas merupakan kelompok marginal ditengah masyarakat. Kondisi baik fisik maupun non fisik dari penyandang disabilitas tersebut berdampak pada kemampuan berpartisipasi ditengah masyarakat. Hal ini pun jauh berdampak pada kepekaan adanya penyandang disabilitas di masyarakat yang kemudian memberikan efek tidak terpenuhinya hak penyandang disabilitas seperti salah satunya ialah hak untuk mendapatkan pekerjaan.

Penyandang disabilitas membutuhkan perhatian dari pemerintah, khususnya dalam hal ketenagakerjaan. Menurut data Badan Pusat Statistik (BPS) tahun 2010 pada 24 provinsi di Indonesia, terdapat 1.235.320 orang penyandang disabilitas, yang terdiri dari 687.020) orang penyandang disabilitas laki-laki, dan 548.300 orang perempuan (Khusus, 2011). Mayoritas dari penyandang disabilitas tersebut termasuk golongan yang berpendidikan rendah. Data menunjukkan, penyandang disabilits yang tidak tamat sekolah dasar sebesar 58,9\%, dan berpendidikan sekolah dasar sebesar 28,1\%. Dengan pendidikan yang masih rendah, ditambah dengan masih banyak penandang disabilitas yang tidak mempunyai keterampilan, membuat para penyandang disabilitas sulit untuk mendapatkan pekerjaan.

Undang-Undang Nomor 8 tahun 2016 tentang Penyandang disabilitas untuk mewujudkan kesamaan hak dan kesempatan bagi penyandang disabilitas menuju kehidupan yang sejahtera, mandiri, dan tanpa diskriminasi yang memberikan landasan hukum secara tegas mengenai kedudukan dan hak penyandang disabilitas. Undang-Undang ini hadir untuk menghapus hambatan bagi penyandang disabilitas dalam pemenuhan hak-hak yang seharusnya sama dengan masyarakat lainnya. Undang-Undang ini menjadi payung hukum untuk melindungi 
penyandang disabilitas dari diskriminasi, termasuk pekerjan. Kemudian dalam Peraturan Daerah Provinsi Bali Nomor 9 Tahun 2015 tentang Perlindungan dan Pemenuhan Hak Penyandang Disabilitas, pasal 13 tentang ketenagakerjaan menyebutkan setiap penyandang disabilitas mempunyai kesamaan hak dan kesempatan untuk mendapatkan pekerjaan dan/atau melakukan pekerjaan yang layak sesuai dengan jenis dan derajat kedisabilitasannya. Ini menunjukkan bahwa penyandang disabilitas seharusnya dapat melakukan pemenuhan hak pekerjaan secara adil sesuai dengan Undang-Undang No 8 Tahun 2016 tentang Penyandang Disabilitas dan Peraturan Daerah Provinsi Bali Nomor 9 Tahun 2015 tentang Perlindungan dan POemenuhan Hak Penyandang Disabilitas.

Pemerintah Daerah Kota Denpasar melalui Dinas Sosial dan Dinas Tenaga Kerja merupakan dua lembaga yang memiliki tanggungjawab dalam pemenuhan hak bagi para penyandang disabilitas dalam mengakses pekerjaan di wilayah Kota Denpasar. Sebagai lembaga yang memiliki tanggungjawab dibidang pekerjaan bagi seluruh masyarakat termasuk didalamnya para penyandang disabilitas, pemahaman lembaga terhadap pekerjaan dan penerima pekerjaan bergantung dari kapasitas yang dimiliki oleh lembaga ini. Apakah mampu untuk menterjemahkan Daerah Provinsi Bali Nomor 9 Tahun 2015 tentang perlindungan dan pemenuhan hak penyandang disabilitas dengan baik sehingga para penyandang disabilitas mampu mengakses pekerjaan seperti masyarakat umum lainnya. Berdasarkan latar belakang yang telah diuraikan di atas, maka peneliti tertarik untuk melakukan penelitian di dinas sosial dan dinas tenaga kerja Kota Denpasar dengan judul Peran Pemerintah Kota Denpasar dalam Mengakomodasi Hak Penyandang Disabilitas dalam Memperoleh Pekerjaan (Suatu Studi di Dinas Sosial Kota Denpasar dan Dinas Tenaga Kerja Kota Denpasar)

\section{METODE}

Penelitian ini menggunakan jenis penelitian kualitatif. Kualitatif digunakan dalam penelitian ini sehingga sangat efektif dalam mencari tanggapan dan pandangan informan secara langsung mellaui wawancara dan observasi langsung. Penelitian ini melibatkan dua belas informan yang terdiri dari 2 dari pihak pemerintah sebagai pihak yang bertanggungjawab dalam menjalankan dan mengawasi terpenuhinya hak pekerjaan bagi penyandang disabilitas. 3 dari penyedia lapangan pekerjaan sebagai pihak yang memberikan pekerjaan bagi penyandang disabilitas, dan 7 dari penyandang disabilitas dari masing-masing derajat kedisabilitasannya sebagai pihak yang merasakan dan menjalan proses pemenuhan hak pekerjaan.

\section{III.HASIL DAN PEMBAHASAN}

Peran Dinas Sosial Kota Denpasar dan Dinas Tenaga Kerja Kota Denpasar terkait Fungsi Pemberdayaan

Peran pemerintah dalam mengakomodasi penyandang disabilitas 
salah satunya melihat peran pemerintah dalam fungsi pemberdayaan. Fungsi pemberdayaan sendiri merupakan fungsi dimana pemerintah melakukan programprogram pemberdayaan guna meningkatkan kualitas masyarakat. Dalam penelitian ini, peran pemerintah yang ditujukan pada fungsi pemberdayaan ialah mengetahui program-program yang dimiliki oleh Dinas Sosial Kota Denpasar dan Dinas Tenaga Kerja Kota Denpasar dalam hal meningkatkan kualitas penyandang disabilitas sehingga mampu bersaing dalam dunia kerja dan mampu mengisi kuota $1 \%$ yang disediakan oleh pemerintah bagi penyandang disabilitas di setiap penyedia lapangan pekerjaan.

Fungsi pemberdayaan yang dijalankan oleh Dinas Sosial Kota Denpasar dan Dinas Tenaga Kerja Kota Denpasar yang kemudian diwujudkan dengan memberikan pelatihan pelatihan yang dibutuhkan oleh penyandang disabilitas.

"kalau tiyang dulu penganggaran sih pernah memberikan pelatihan pijat. Pelatihan membuat udeng, bokoran

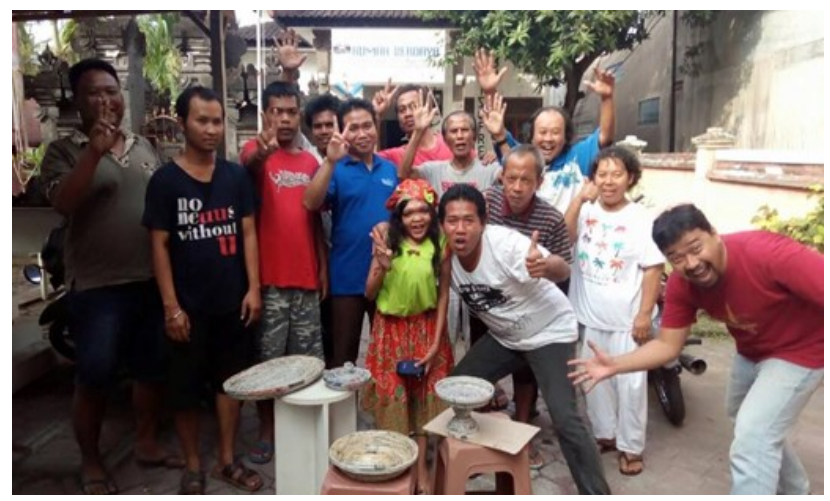

dari koran untuk disabilitas gabungan seperti tuna netra, tuna rungu dan disabilitas mental. Pelatihan nike memang ada tahun lalu. Tapi penganggaran untuk tahun ini memang tidak ada. Cuma kita bekerjasama dengan Dinsos provinsi. Kemarin dinsos provinsi memfasilasi mereka spa. Karena ada bantuan dana dari dinsos mereka diarahkan ke Spa. Pijat spa disabilitas itu bahkan lebih bagus dari yang normal.". (Denpasar, 2018)

Dari petikan hasil wawancara diatas dapat dilihat bahwa Dinas Sosial Kota Denpasar selalu berusaha untuk memberikan pelatihan bagi penyandang disabilitas. Hal ini untuk membantu penyandang disabilitas memiliki kemampuan yang dapat digunakan untuk memberdayakan diri ke depannya. Untuk memperjelas bagaimana pelatihan yang dilakukan oleh Dinas Sosial Kota Denpasar kepada penyandang disabilitas dapat dilihat pada gambar dibawah ini.

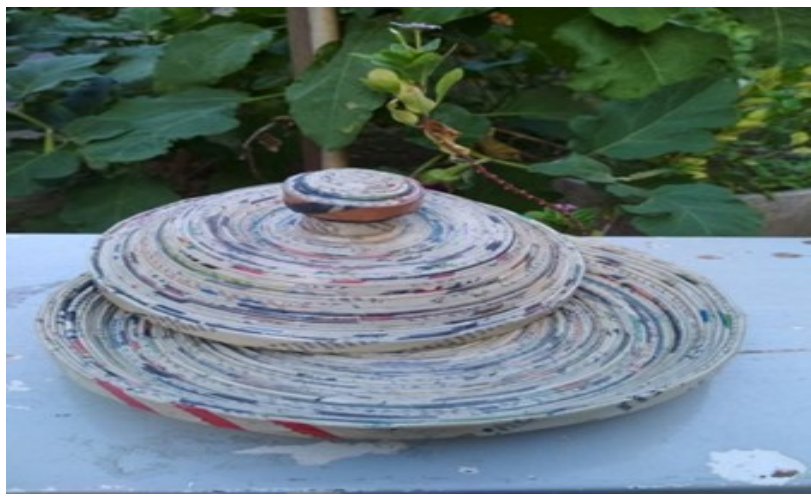

Gambar 1. Pelatiahan Pembuatan Bokor

Sumber: https://www.facebook.com/pg/rumahberdaya.kpsibali/photos 
Pada gambar diatas dapat dilihat bahwa penyandang disabilitas juga dapat melakukan hal-hal yang dilakukan oleh masyarakat pada umumnya. Bahkan kadang kala kemampuan penyandang disabilitas lebih baik dibandingkan masyarakat pada umumnya. Hal ini pun diungkapkan oleh instruktur pelatihan pijat spa seperti yang telah dijabarkan pada petikan wawancara oleh PM1 diatas. Dari pernyataan yang diungkapkan oleh instruktur yang diungkap kembali oleh PM1 juga secara tidak sadar membuka pintu yang selama membatasi penyandang disabilitas. Selama ini tidak dapat dipungkiri bahwa stigma masyarakat kental akan ketidakmampuan penyandang disabilitas untuk melakukan kegiatan layaknya masyarakat umum.

Pelatihan bagi penyandang disabilitas tidak hanya dilakukan oleh Dinas Sosial Kota Denpasar melainkan juga diberikan oleh Dinas Tenaga Kerja Kota Denpasar. Sebagai pihak yang juga memiliki tanggungjawab untuk dapat memberikan akses bagi penyandang disabilitas dalam memperoleh pekerjaan, Dinas Tenaga Kerja memberikan pelatihan yang berbeda dari pelatihan yang diberikan oleh Dinas Sosial Kota Denpasar bagi penyandang disabilitas.

"iya kita memberikan pelatihan bagi penyandang disabilitas. Kemarin kebetulan ada kerjasama dengan pusat sehigga kita bisa melaksanakan pelatihan pelatihan. Ya kita memang tidak ada anggaran untuk kesana. Tapi biasanya ada kerjasama dengan pusat.
Pelatihan yang baru-baru ini kita lakukan adalah ternak lele. Kita menggubungi Gergatin ada pelatihan mau atau gak. Terus langsung digerakkan anggotanya" (Denpasar K. P., 2018)

Dari ungkapan Informan PM2 diatas dapat dilihat bahwa pelatihan yang diberikan baik oleh Dinas Sosial Kota Denpasar dan juga Dinas Tenaga Kerja Kota Denpasar telah beragam bentuknya. Apabila dianalisis dengan menggunakan moral model disability, yang dilakukan oleh Dinas Sosial Kota Denpasar dan juga Dinas Tenaga Kerja Kota Denpasar merupakan langkah awal yang baik. Seperti yang diketahui, di Indonesia sendiri banyak disabilitas yang tidak mau berkegiatan yang diakibatkan oleh stigma masyarakat yang buruk dan juga lebel tidak mampu seperti dalam moral model disability. Namun dengan adanya keaktifan pelatihanpelatihan yang dilakukan juga secara tidak langsung mengahapuskan stigma tersebut dan kian menyadarkan penyandang disabilitas dapat melakukan banyak hal. Berikut ilaha gambar pelatihan ternak lele yang diberikan oleh Dinas Tenaga Kerja Kota Denpasar.

Dari Gambar 2 dapat dilihat bahwa kapasitas pelatihan tidaklah besar. Sehingga tidak seluruh penyandang disabilitas dapat turt mengikuti pelatihan yang diberikan. Selain itu, Pemerintah biasanya akan bekerjasama dengan organisasi penyandang disabilitas. Hal ini juga diungkapkan oleh PM2. 

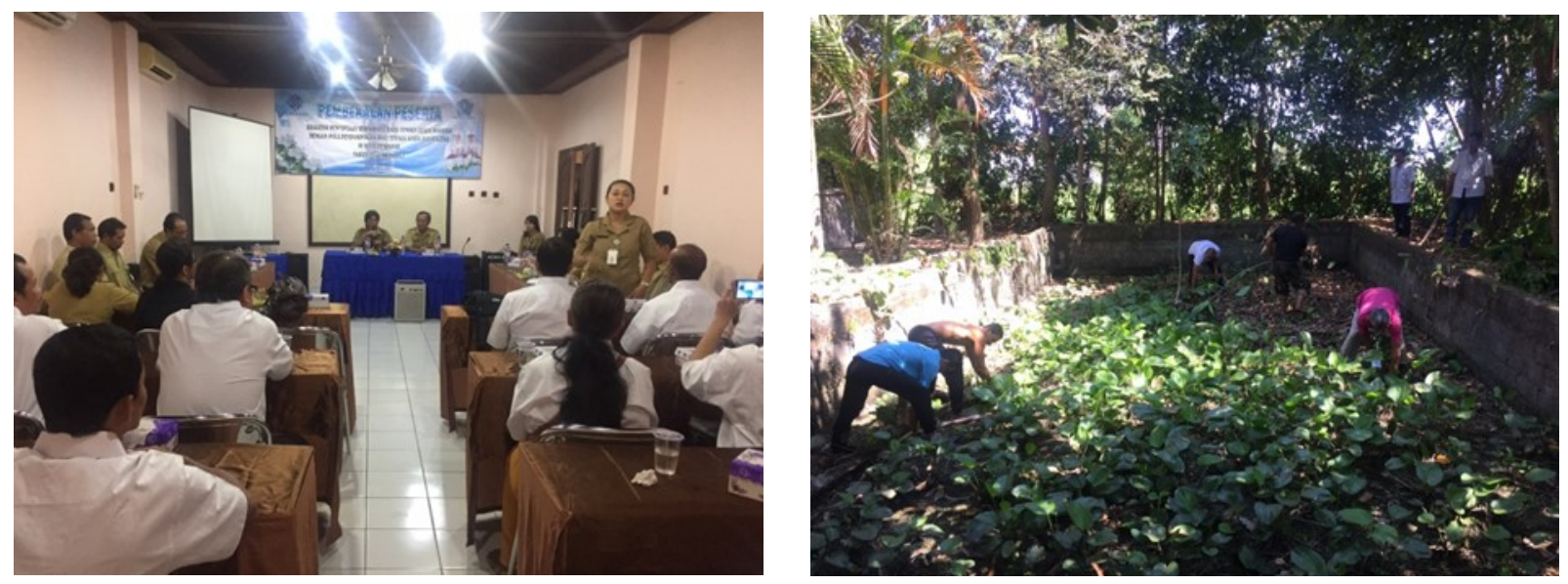

Gambar 2. Pelatihan Ternak Lele bagi Penyandang Disabilitas

Sumber: Dinas Tenaga Kerja Kota Denpasar

"Kita menggubungi Gergatin ada pelatihan mau atau gak. Terus langsung digerakkan anggotanya. Kan mereka yang lebih tau butuh pelatihan apa dan siapa anggotanya. Lebih mudah lah ngumpulin. Mereka juga semangat semangat." (Denpasar K. P., 2018)

Dari pernyataan PM2 diatas dapat diketahui bahwa hanya penyandang disabilitas yang aktif di organisasi penyandang disabilitas yang lebih memiliki akses untuk memperoleh pelatihan. Pemerintah cenderung menyebarkan informasi kepada organisasi-organisasi penyandang disabilitas. Baik Dinas Sosial Kota Denpasar dan Dinas Tenaga Kerja Kota Denpasar mengajak organisasi seperti Gergatin, pertuni ataupun LSM yang bergerak dibidang disabilitas yang dapat menjamin keaktifan anggotanya.

Terkait dengan ungkapan baik dari Informan PM1 dan PM2 yang cenderung menghubungi organisasi penyandang disabilitas sehingga menimbulkan dua sisi bagi penyandang disabilitas. Sisi berbeda dari pemberdayaan ini muncul ketika fungsi pemberdayaan yang dijalankan oleh Dinas Sosial Kota Denpasar dan Dinas Tenaga Kerja Kota Denpasar dengan memberikan pelatihan kepada penyandang disabilitas ini disandingkan dengan konsep penerima manfaat pemberdayaan masyarakat. Dimana konsep pemberdayaan merupakan sebuah proses menuju berdaya atau pemberian daya/kekuatan, sedangkan dari konsep penerima manfaat pemberdayaan akan terlihat bahwa penerima manfaat merupakan kelompok yang memiliki kedudukan yang berbeda. Karena penerima manfaat digolongkan sebagai kelompok tidak berdaya maka dianggap kelompok yang lebih lemah dibandingkan dengan kelompok pemberi pemberdayaan yang dalam penelitian ini ialah Dinas Sosial Kota Denpasar dan Dinas Tenaga Kerja Kota Denpasar dan penerima manfaat dari adanya pemberdayaan ialah penyandang disabilitas. Dengan kata lain pelatihan ini secara tidak langsung 
mengarah pada pengelompokkan penyandang disabilitas sebagai kelompok yang yang berbeda yakni kelompok tidak berdaya. Padahal seharusnya penerima manfaat menurut konsep penerima manfaat, bukanlah obyek atau sasaran yang harus dibedakan berdasarkan kedudukan si penerima dan si pemberi. Atas dari inilah pemberdayaan pada dasarnya memiliki dua sisi yang berjalan berlawanan arah.

Terlepas dari pemberdayaan yang memiliki dua sisi yang berbeda yakni dapat dilihat dari konsep dasar pemberdayaan dan juga dari sisi penerima manfaat, pelatihan yang diberikan oleh Dinas Sosial Kota Denpasar dan Dinas Tenaga Kerja Kota Denpasar khususnya sudah mampu memberikan pelatihan yang dapat menjadi bekal penyandang disabilitas.

"Sekarang saya mijet. Pelatihannya dapat dulu. Kalau dulu pernah mengikuti pelatihan pijat di dinas sosial Kota Denpasar, terus di Provinsi Bali juga dulu pernah tahun 2009an pernah mengadakan kursus pijat. Kalo saya dulu pernah kursusnya lama di Bandung itu selama 2 tahun. Kalo secara pendidikan saya nggak pernah mengikuti di Bali kebetulan itu tempatnya di Mahatmia di Tabanan, sedangkan pendidikan formalnya di Griya Laba." (Netra, 2018)

Dari data Informan TN3 diatas dapat dilihat bahwa adanya pelatihan yang diberikan oleh Dinas Sosial Kota Denpasar dapat menjadikan penyandang disabilitas lebih berdaya. Berdaya yang dimaksud ialah penyandang disabilitas mampu untuk bekerja sehingga mampu membiaya kehidupan sendiri.

Meski penyandang disabilitas telah mendapatkan pelatihan guna meningkatkan kemampuan diri sehingga penyandang disabilitas mampu berdaya, penyandang disabilitas sendiri masih menilai terdapat kekurangan dari pelatihan yang diberikan oleh pemerintah. Hal inipun diungkapkan oleh Informan TN3

"Ya namanya diberikan kursus secara gratis itu kursusnya menurut saya terlalu singkat sehingga ilmunya kurang padat mestinya ilmunya 1 bulan tapi diambil nya satu minggu dan itu pun hanya beberapa jam saja dan terkadang instrukturnya itu memberikan ilmu cuma sekedar itu yang saya rasakan." (Netra, 2018)

Ungkapan TN3 ini memberikan informasi bagi pemerintah bahwa dalam mendesain suatu pelatihan haruslah lebih jauh agar pelatihan yang diberikan tidak hanya sekedar pelatihan. Pelatihan penyandang disabilitas bukanlah pelatihan yang diselenggarakan hanya untuk melaksanakan kewajiban semata.

Kurangnya pelatihan yang diberikan oleh baik itu Dinas Sosial Kota Denpasar ataupun Dinas Tenaga Kerja Kota Denpasar juga diungkapkan oleh Informan TD2.

"saya kan cacat kaki tapi lainnya biasa normal. Jadi pelatihan yang ada di pemerintah itu lebih kepada pijat 
untuk tuna netra biasanya. Padahal saya tidak memerlukan itu. Saya lebih perlu pelatihan seperti komputer. Saat ini bagaimana kita bisa bersaing dengan pekerja normal, sedangkan teknologi mendasar yang digunakan sekarang saja kita tidak mampu". (Daksa, 2018)

Ungkapan dari Informan TD2 diatas menunjukkan bahwa penyandang disabilitas merasa bahwa pelatihan yang diberikan hanya berkisar pada ketrampilanketrampilan dasar sehingga penyandang disabilitas merasa pelatihan yang diberikan kurang memberikan manfaat baru bagi penyandang disabilitas. Hal ini dapat mengindikasikan bahwa penerima manfaat yakni penyandang disabilitas hanya dilihat sebagai obyek pemberdayaan atau sasaran pemberdayaan sehingga penentuan pelatihan hanya berjalan searah tanpa melihat kebutuhan penyandang disabilitas itu sendiri. Padahal apabila disesuaikan dengan konsep penerima manfaat, seharusnya penyandang disabilitas dianggap sebagai rekan sekerja yang dapat diajak bertukar pikiran dan berdiskusi termasuk dalam penentuan jenis pelatihan yang diberikan pada diri penyandang disabilitas itu sendiri.

Tidak hanya diungkapkan oleh Informan TD2 saja bahwa pelatihan ketrampilan dasar yang diberikan oleh departemen sosial tidak dapat memberikan manfaat lebih. Informan TD1 pun mengungkapkan demikian

"biasanya kan pelatihannya jahit saja bagi tuna daksa. Itu-itu terus. Diidentikkanlah tuna daksa biasanya diberikan ketrampilan jahit.. Padahal kan perusahaan tidak hanya garmen atau tidak hanya butuh yang bisa jahit. Tapi juga butuh ketrampilan lainnya. Pemerintah kurang peka terhadap perubahan kebutuhan perusahaan." (Netra (. P., 2018)

Pernyataan yang diungkapkan oleh Informan TD1 ini memperjelas keadaan bahwa pelatihan yang diberikan oleh Dinas Sosial Kota Denpasar dan Dinas Tenaga Kerja Kota Denpasar tidak dapat memberikan manfaat baru bagi penyandang disabilitas untuk dapat bersaing dalam dunia pasar kerja. Padahal sesuai dengan konsep dasar dimana pemberdayaan dilakukan untuk dapat meningkatkan kualitas penyandang disabilitas sehingga dapat bersaing pada dunia kerja. Namun pada kenyataannya pelatihan yang diberikan tidak berjalan sesuai dengan konsep dasar pemberdayaan. Pelatihan tidak meningkatkan kemampuan penyandang disabilitas untuk dapat bersaing dalam dunia kerja.

Tidak menjawab kebutuhan pasar kerja sesuai yang diungkapkan oleh Informan TD1 dan Informan TD2 apabila dikaitkan dengan hasil wawancara dengan Dinas Sosial Kota Denpasar dan Dinas Tenaga Kerja Kota Denpasar akan terjadi ketidakcocokan didalamnya. Apabila melihat kembali petikan wawancara PM1 dan PM2, dapat dilihat bahwa keterbatasan anggaran yang dimiliki oleh Pemerintah Kota yang mana dalam hal ini ialah Dinas 
Sosial dan Dinas Tenaga Kerja Kota Denpasar menyebabkan pelatihan yang diberikan kurang berkembang atau jarang dilakukan. Bahkan yang lebih menyebabkan pernyataan kedua belah pihak terlalu kontras karena memang peserta penyandang disabilitas yang biasanya ikut dalam pelatihan yakni anggota aktif dari sebuah organisasi.

Sudut pandang yang menekankan pelatihan yang diungkapkan oleh beberapa penyandang disabilitas memnag sangat jauh berbeda dengan DNetwork. DNetwork merupakan salah satu yayasan yang bergerak di bidang penyaluran tenaga kerja penyandang disabilitas.

\section{Peran Dinas Sosial Kota Denpasar dan Dinas Tenaga Kerja Kota Denpasar terkait Fungsi Pelayanan}

Sosialisasi kepada penyedia lapangan pekerjaan merupakan salah satu kegiatan yang dilakukan oleh Dinas Tenaga Kerja Kota Denpasar dalam mewujudkan fungsi pelayanan bagi penyandang disabilitas untuk memberikan pemenuhan hak penyandang disabilitas. Hal ini pun diungkapkan oleh informr PM2.

"yang namanya disabilitas tidak bisa diselesaikan oleh misalnya Dinas Sosial saja atau Dinas Tenaga Kerja saja. Disabilitas harus diselesaikan oleh semua pihak. Kalau berbicara tentang kuota pekerjaan, memang lebih condong ke Dinas Tenaga Kerja yang melakukan. Kalau kita penyampaian lowongan pekerjaan pasti dibararengi dengan sosialisasi tentang disabilitas secara umum. Pada dasarnya agar mereka lebih peka bahwa ada disabilitas" (Denpasar K. P., 2018)

Seiring dengan pernyataan Informan D2 diatas bahwa kewajiban pemerintah khususnya Dinas Tenaga Kerja Kota Denpasar dalam mensosialisasikan kepada penyedia lapangan pekerjaan akan keberadaan disabilitas sesuai dengan kewajiban pemerintah untuk mengimplementasikan kebijakan yang telah dibuat. Kebijakan yang dimaksud ialah Peraturan Daerah Provinsi Bali Nomor 9 Tahun 2015 tentang Perlindungan dan Pemenuhan Hak Penyandang Disabilitas. Meski peraturan pemerintah tentang disabilitas berada pada tingkat provinsi, bukan berarti pemerintah Kota Denpasar tidak wajib menjalankan peraturan tersebut.

Sosialisasi dilakukan untuk meningkatkan penyedia lapangan pekerjaan akan kewajiban yang dimiliki yakni mempekerjakan penyandang disabilitas. Sosialisasi dipilih oleh Dinas Tenaga Kerja Kota Denpasar mengingat keadaan yang saat ini terjadi. Meski penyedia lapangan pekerjaan telah mengetahui bahwa terdapat kebijakan yang mengatur bahwa setiap penyedia lapangan pekerjaan harus mampu menyediakan akses yang sama bagi penyandang disabilitas dalam mengakses pekerjaan.

Meski Dinas Tenaga Kerja Kota Denpasar telah memberikan informasi terkait pemberian hak pekerjaan bagi 
penyandang disabilitas namun hal tersebut tidak sesuai dengan pernyataan yang diungkapkan oleh Informan P1.

“yaa kita sering ada kegiatan dengan pemerintah, dengan Dinas Tenaga Kerja atau dengan pihak lainnya tentang tenaga kerja. Biasanya tentang tenaga kerja dan CSR Tapi kalau sosialisasi khusus tentang disabilitas saya rasa belum pernah mbak...ya kita tau mbak tentang kuota tersebut. tapi agak susah." (Tiara Dewata, 2018)

Dari petikan wawancara diatas dapat dilihat bahwa masih ada penyedia lapangan pekerjaan yang tidak menerima sosialisasi tentang disabilitas khususnya sosialisasi tentang kuota yang harus disediakan oleh setiap penyedia lapangan pekerjaan bagi penyandang disabilitas. Hal ini tidak hanya terjadi pada satu penyedia lapangan pekerjaan saat. Balidecoupage selaku penyedia lapangan pekerjaan yang bergerak di bidang usaha ekonomi kreatif juga belum pernah mendapatkan sosialisasi terkait pemberian akses pada penyandang disabilitas dalam memperoleh pekerjaan.

"sosialisasi-sosialisasi seperti itu gak ada. Tapi kita tidak pernah menutup kalau penyandang disabilitas ada yang mau bekerja disini." (Tiara Dewata, 2018)

Hal serupa pun diungkapkan oleh Informan PL3

"gak ada mbak. Belum pernah ada sosialisasi tentang hal tersebut." (Decocraft, 2018)
Dari hasil wawancara kedua penyedia lapangan pekerjaan diatas, salah satu diantara belum ada yang menerima sosialisasi terkait pemberian akses yang sama bagi penyandang disabilitas dan juga terkait kuota $1 \%$ yang harus disediakan oleh penyedia lapangan pekerjaan bagi penyandang disabilitas. pada dasarnya sosialisasi ini dilaksanakan tidak hanya untuk mengalakkan selurh penyedia lapangan kerja menyediakan kuota 1\% dan memberikan akses yang sama bagi penyandang disabilitas dalam memperoleh pekerjaan. Melainkan menumbuhkan kesadaran bahwa penyandang disbailitas ada diantara masyarakat. dna penyandang disabilitas memiliki hak yang sama atas pemenuhan hak dengan masyarakat umum.

Berdasarkan ketiga penyedia lapangan pekerjaan sebagai pihak yang terkena dampak langsung dari peran pemerintah, dapat disimpulkan bahwa sosialisasi yang telah dijalankan oleh Dinas Tenaga Kerja Kota Denpasar masih belum maksimal. Mengingat salah satu penyedia lapangan pekerjaan yang menjadi objek penelitian merupakan salah satu perusahaan besar yang telah ada di Kota Denpasar lebih dari 20 tahun pun belum menerima sosialisasi khusus terkait penerimaan penyandang disabilitas di penyedia-penyedia lapangan pekerjaan. Sosialisasi kepada penyandang disabilitas masih harus digiatkan oleh Dinas Tenaga Kerja dan Kota Denpasar. Melihat dari penyedia lapangan yang menjadi objek penelitian pekerjaan masih belum mendapatkan sosialisasi tentang adanya kuota bagi penyandang disabilitas untuk 
dapat bekerja dalam suatu penyedia lapangan pekerjaan.

Tidak hanya berhenti pada sosialisasi yang tidak maksimal, tidak pernahnya menerima sosialisasi tentang akses pada penyandang disabilitas dapat menjadi evaluasi bagi Dinas Tenaga Kerja Kota Denpasar. Evaluasi ini dapat menjadi acuan bagi pemerintah untuk dapat merancang strategi sosialisasi yang merata dan dapat diterapkan oleh penyedia lapangan pekerjaan. Hal ini pun dapat memberikan dampak positif bagi terlaksananya kuota $1 \%$ yang harus disediakan oleh penyedia lapangan pekerjaan sesuai dengan Peraturan Pemerintah Provinsi Bali Nomor 9 Tahun 2015 tentang Perlindungan dan Pemenuhan Hak Penyandang Disabilitas.

\section{Menghubungkan penyedia lapangan pekerjaan dengan penyandang disabilitas}

Menghubungkan penyedia lapangan pekerjaan dengan penyandang disabilitas merupakan bagian dari kegiatan yang dilakukan D Dinas Tenaga Kerja Kota Denpasar. Menghubungkan penyedia lapangan pekerjaan dengan penyandang disabilitas merupakan salah satu cara mempromosikan para penyandang disabilitas kepada penyedia lapangan pekerjaan. Adanya kegiatan ini akan sangat membantu penyandang disabilitas dan juga penyedia lapangan pekerjaan untuk saling memenuhi kebutuhan masing-masing. Penyandang disabilitas mengetahui akses ke penyedia lapangan kerja dan begitu juga sebaliknya dengan penyedia lapangan kerja yang membutuhkan penyedia lapangan pekerjaan.

Tidak mengetahui informasi tentang lapangan pekerjaan yang membutuhkan penyandang disabilitas dan begitu juga dengan penyedia lapangan pekerjaan tentang penyandang disabilitas yang siap bekerja menjadi salah satu hambatan tidak terisinya posisi-posisi bagi penyandang disabilitas di penyedia lapangan pekerjaan yang membuka posisi untuk penyandang disabilitas.

"kita disini bukannya tidak mau mempekerjakan disabilitas. Tapi kita gak tau harus menghubungi kemana. Apa kemampuan mereka apa aja. Kita tidak membedakan dia disabilitas atau tidak selama punya kemampuan yang dibutuhkan. Minimal dasar-dasarnya. Nanti disini kan dilatih lagi." (Balidecoupage, 2018)

Minimnya informasi terkait penyandang disabilitas merupakan salah satu hambatan bagi penyandang disabilitas untuk memperoleh pekerjaan. Apabila dianalisis berdasarkan data Informan PL2, seorang penyandang disabilitas dapat memiliki pekerjaan atau tidak, tidak semata -mata hanya disebabkan oleh label yang melekat pada diri seorang penyandang disabilitas. Melainkan ketersediaan informasi bagi para penyedia lapangan pekerjaan tentang penyandang disabilitas.

Ketersediaan informasi tentang profil penyandang disabilitas menjadi hal yang penting bagi kemudahan penyedia lapangan pekerjaan mencari penyandang 
disabilitas yang siap kerja. Pendapat yang diungkapkan oleh Informan PL2 pun selaras dengan pendapat Informan PL3.

"boleh-boleh saja kalau mau bekerja disini. Saya akan menerimanya sepanjang punya kemampuan jahit dasar. Karena disini kan saya perlu jahit tas dan lainnya. Tapi saya gak tau dimana mencari disbilitas. Selain itu sampai saat ini tidak ada disabilitas yang coba daftar kesini." (Decocraft, 2018)

Data dari Informan PL3 ini kian menguatkan bahwa tidak semua penyedia lapangan pekerjaan melihat label yang melekat pada penyandang disabilitas yang identic dengan ketidakmampuan dan keterbatasan. Para penyedia lapangan pekerjaan lebih menekankan pada kamuan untuk belajar dan kemampuan/skill yang dimiliki.

Permasalahan sulitnya mencari penyandang disabilitas yang siap kerja tidak hanya dirasakan oleh penyedia lapangan pekerjaan. Sulitnya mencari penyedia lapangan pekerjaan yang menerima penyandang disabilitas juga dirasakan oleh penyandang disabilitas itu sendiri.

“ saya kan gak bisa bicara, yang mau nerima saya kerja juga pasti sedikit. Gak tau yang mau nerima saya dimana. Dulu pernah kerja cuci motor, tapi sekarang sudah tutup. Sejak tutup enggak kerja. Bantu-bantu aja biasanya." (Rungu, 2018)
Dari Informan TR1 dapat diketahui bahwa penyandang disabilitas pun tidak memiliki informasi terkait ketersedian penyedia lapangan pekerjaan yang siap mempekerjakan penyandang disabilitas. Tidak dapat dipungkiri tidak semua penyedia lapangan pekerjaan yang siap menerima penyandang disabilitas. Maka dari itu adanya informasi terkait penyedia lapangan pekerjaan yang siap menerima penyandang disabilitas sangat diperlukan oleh penyandang disabilitas.

Terbatasnya informasi terkait penyedia lapangan pekerjaan yang siap menerima penyandang disabilitas juga dirasakan oleh Informan TN2 yang merupakan seorang penyandang disabilitas tuna netra.

“Jelas adaa dik, masalah pekerjaan itu yang jelas susah atau bisa dikatakan kekurangan. Kurang tahu dimana saya bisa kerja. Kemudian yang kedua pemerintah memberikan kemudahan untuk penyandang tuna netra dalam mencari pekerjaan agar sedikit tidaknya ada satu perusahan menerima tuna netra gitu aja intinya,." (Netra (. P., 2018)

Permasalahan yang dirasakan oleh Informan TN2 tidak jauh berbeda dari Informan TR1. Tidak mengetahui penyedia lapangan pekerjaan yang siap menerima penyandang disabilitas menjadikan Informan TN2 tidak memiliki pekerjaan sampai saat ini. Padahal keinginan untuk bekerja dari penyandang disabilitas melalui Informan TN2 harus diapresiasi. Keinginan 
untuk bekerja oleh Informan TN2 secara tidak langsung mendorong keinginan untuk keluar dari stigma masyarakat yang menganggap penyandang disabilitas tidak mapu untuk melakukan aktivitas layaknya masyarakat umum.

Ketersediaan informasi penyandang disabilitas dan juga penyedia lapangan pekerjaan yang siap menerima penyandnag disabilitas menjadi sangat baik bagi kedua belah pihak. Hal inilah yang kemudian disadari oleh Dinas Tenaga Kerja Kota Denpasar. Namun hingga saat ini, Dinas Tenaga Kerja belum sampai pada proses penyaluran tenaga kerja dengan status penyandang disabilitas kepada penyedia lapangan pekerjaan. Dinas Tenaga Kerjan Kota Denpasar baru Hal ini diungkapkan oleh Informan PM2,

"Secara resmi buka bagian khusus penyaluran tenga kerja disabilitas ke penyedia lapangan pekerjaan belum ada. Tapi sejauh ini berusaha menghubungkan penyandang disabilitas ke penyedia lapangan pekerjaan yang membutuhkan penyandang disabilitas. kalau misalnya perusahaan mana perlu, kita bantu hubungkan melalui organisasnya." (Denpasar K. P., 2018)

Meski Dinas Tenaga Kerja Kota Denpasar belum memiliki bagian khusus yang bertigas untuk menyalurkan penyandang disabilitas kepada penyedia lapangan pekerjaan yang membutuhkan tenaga penyandang disabilitas, namun dengan adanya usaha kecil dari dinas berupa menghubungkan secara sederhana antara penyedia lapangan pekerjaan dan penyandang disabilitas akan sangat membantu penyandang disabilitas yang mau dan mampu bekerja.

Apabila terwujudnya penghubung penyedia lapangan pekerjaan dan penyandang disabilitas menekankan pada keaktifan penyedia lapangan pekerjaan semata maka terpenuhnya hak penyandang disabilitas akan sulit terwujud. Untuk membangun kesadaran penyedia lapangan pekerjaan untuk membuka akses pekerjaan bagi penyandang disabilitas saja mengalami kesulitan. Apalagi untuk aktif menghubungi mencari penyandang disabilitas yang siap kerja ataupun menghubung pemerintah untuk menginformasikan membutuhkan penyandang disabilitas.

\section{IV.SIMPULAN}

Kesimpulan yang dapat diambil pada penelitian ini yakni peran pemerintah dalam mengakomodasi penyandang disabilitas dalam memperoleh pekerjaan belum dapat berjalan sesuai dengan yang diharapkan. Berbagai kekurangan pun masih terjadi dalam berbagai peran yang dilakukan Dinas Sosial Kota Denpasar dan Dinas Tenaga Kerja Kota Denpasar sehingga peran pemerintah dalam menjalankan fungsi pemberdayaan dan fungsi pelayanan tidak dapat berjalan maksimal.

Kekurangan yang menyebabkan belum maksimalnya peran pemerintah yakni kegiatan pelatihan yang diadakan 
oleh Dinas Sosial Kota Denpasar dan Dinas Tenaga Kerja Kota Denpasar yakni pada dasarnya ialah anggaran dan yang minim sehingga pelatihan jarang dan sulit berkembang. Selain itu, pelatihan cenderung tidak menyebar karena pada dasarnya pemerintah mengajak oragnisasi penyandang disabilitas dalam mendukung pelatihan yang dibuat. Sehingga angota organisasi memiliki kesempatan lebih untuk ikut dalam pelatihan disbanding penyandang disabilitas diluar oragnisasi. Inilah yang menyebabkan pelatihan gterliat tidak menyeluruh.

Kegiatan pelayanan yang diadakan oleh Dinas Tenaga Kerja Kota Denpasar dalam menjalankan fungsi pelayanan yang diwujudkan dengan memberikan sosialisasi terkait penerimaan penyandang disabilitas pada penyedia lapangan pekerjaan dan menjadi penghubung anatara penyedia lapangan pekerjaan dan penyandang disabilitas. Hanya saja, tidak meratanya sosialisasi menjadi kekurangan dalam kegiatan sosialisasi yang diadakan oleh Dinas Sosial Kota Denpasar dan Dinas Tenaga Kerja Kota Denpasar. Nyatanya dari ketiga objek penyedia lapangan pekerjaan di dalam penelitian ini, ketiga penyedia lapangan pekerjaan belum pernah mendapatkan sosialisasi khusus terkait adanya kuota $1 \%$ bagi penyandang disabilitas di setiap penyedia lapangan pekerjaan.

Kekurangan yang terjadi dalam pelayanan kedua yaitu sebagai penghubung antara penyedia lapangan pekerjaan dan penyandang disabilitas ialah kurang aktifnya Dinas Tenaga Kerja Kota Denpasar. Selama ini, Dinas Tenaga Kerja Kota Denpasar akan menghubungkan penyedia lapangan pekerjaan dengan penyandang disabilitas ketika penyedia lapangan pekerjaan menghubungi Dinas Tenaga Kerja Kota Denpasar terlebih dahulu.

\section{DAFTAR PUSTAKA}

Balidecoupage. (2018, Juli 19). Peran Pemerintah dalam Mengakomodasi Hak Penyandang Disabilitas dalam Mengakses Pekerjaan . (E. Marsitadewi, Interviewer)

Daksa, (. P. (2018, Agustus 19). Peran Pemerintah dalam Mengakomodasi Hak Penyandang Disabilitas dalam Mengakses Pekerjaan . (E. Marsitadewi, Interviewer)

Decocraft. (2018, Juli 18). Peran Pemerintah dalam Mengakomodasi Hak Penyandang Disabilitas dalam Mengakses Pekerjaan . (I. P. Ema Mrsitadewi, Interviewer)

Denpasar, K. P. (2018). Peran Pemerintah dalam Mengakomodasi Hak Penyandang Disabilitas dalam Mengakses Pekerjaan . (E. Marsitadewi, Interviewer)

Denpasar, K. R. (2018). Peran Pemerintah dalam Mengakomodasi Hak Penyandang Disabilitas dalam Mengakses Pekerjaan . (E. Marsitadewi, Interviewer)

Khusus, S. D. (2011). OPedoman Penempatan Tenaga Kerja Penyandang Cacat Lanjut Usia dan Wanita. Jakarta: Kementrian Tenaga Kerja dan Transmigrasi Republik Indonesia.

Muhtaj, M. E. (2008). Dimensi-Dimensi HAM Mengurai Hak Ekonomi, Sosial dan Budaya. Jakarta: Raja Grafindo Persada.

Netra, (. P. (2018, Juli 10). Peran Pemerintah dalam Mengakomodasi Hak Penyandang Disabilitas dalam Mengakses Pekerjaan. (E. Marsitadewi, Interviewer)

Netra, (. P. (2018, Juli 6). Peran Pemerintah dalam 
POLITICOS: Jurnal Politik dan Pemerintahan, 1 (2) (2021)

Peran Pemerintah Kota Denpasar Dalam Mengakomodasi Hak Penyandang Disabilitas Dalam Memperoleh Pekerjaan

Mengakomodasi Hak Penyandang Disabilitas dalam Mengakses Pekerjaan . (E. Marsitadewi, Interviewer)

Netra, (. P. (2018, Juli 10). Peran Pemerintah dalam Mengakomodasi Hak Penyandang Disabilitas dalam Mengakses Pekerjaan . (E. Marsitadewi, Interviewer)

Rungu, P. D. (2018, Agustus 30). Peran Pemerintah dalam Mengakomodasi Hak Penyandang Disabilitas dalam Mengakses Pekerjaan . (E. Marsitadewi, Interviewer)

Tiara Dewata, K. B. (2018, Juli 19). Peran Pemerintah dalam Mengakomodasi Hak Penyandang Disabilitas dalam Mengakses Pekerjaan . (I. P. Ema Marsitadewi, Interviewer) 